\title{
Molecular Characterization of Olive Cultivars Using RAPD Markers
}

\author{
F. Sanz-Cortés, M.L. Badenes, S. Paz, ${ }^{1}$ A. Íñiguez, ${ }^{1}$ and G. Llácer \\ Instituto Valenciano de Investigaciones Agrarias, Apartado Oficial, 46113 Moncada, Valencia, Spain
}

\begin{abstract}
AdDitional INDEX wORDs. genetic typing, Olea europaea, cultivar identification
Abstract. Forty olive (Olea europaea L.) cultivars from Valencia, Spain, were screened using random amplifiedpolymorphic DNA (RAPD) markers. Eighteen selected decamer primers produced 34 reproducible amplification fragments that were then used as polymorphic markers. The resulting combinations of these RAPD markers were used to discriminate 40 cultivars. Results were analyzed for similarity among cultivars and the relatedness of polymorphisms obtained between cultivars agreed with previous results using isozymes. Unweighted pair group method cluster analysis of their similarity values revealed two main groups divided according to geographic origin within Valencia. A third group, which included two Spanish cultivars from regions outside of Valencia, was clustered separately from the Valencian cultivars. RAPD technology proved useful in discriminating closely related cultivars. There was no apparent clustering of cultivars by fruit size or other morphological traits.
\end{abstract}

The olive tree originated on the eastern shores of the Mediterranean (Zohary and Spiegel-Roy, 1975). It is the most ancient cultivated tree fruit species in the Mediterranean basin and was spread throughout the Mediterranean region by Phoenicians, Greeks, and Romans. The species belongs to the Oleaceae, which comprises 29 genera.

The genus Olea L. includes other 35 species distributed mainly over tropical areas. Olea europeae is the only species from this genus adapted to the Mediterranean. Ease of propagation of seedlings along with cultivar intercompatibility resulted in a high degree of diversity with a large number of native cultivars in areas where the crop has been established. There are more than 2000 cultivars from this species grown in the world. Current trends point towards increasing acreage. Olive oil has been reported as a healthy source of fats, which has led to an increase in its consumption. World olive oil production continues to increase in order to meet demand. However, production is based on native cultivars that differ from one cropping area to another.

Conservation of germplasm is the key to improve production. For instance, in Spain there are six main growing regions and $\approx 262$ different cultivars are grown (Barranco, 1998). This large diversity in cultivars is invaluable for germplasm resources as well as for research. Although Valencia is not an important olive crop area in terms of acreage, it has the largest phenotypic diversity among cultivars in Spain (Iñiguez et al., 1999). In 1994 a survey of olive clones identified 217 accessions from the Valencia region, which were established as a germplasm collection. Morphological and phenological traits were used to identify olive cultivars (Iñiguez et al., 1999) following Barranco and Rallo (1985), resulting in the discrimination of 74 different cultivars. However, diseases and environmental factors can affect these traits, leading to a wrong identification. From previous results obtained through pomological characterization, we have convincing evidence that some accessions in the collection are in fact mislabeled. Correct identification of germplasm resources is of obvious importance to plant material management.

\footnotetext{
Received for publication 21 Dec 1999. Accepted for publication 31 July 2000 . We thank Dr. Robert G. Fjellstrom and two anonymous reviewers for assistance in revision and improvement of this manuscript. F.S-C. was funded by a fellowship from Instituto Valenciano de Investigaciones Agrarias. The cost of publishing this paper was defrayed in part by the payment of page charges. Under postal regulations, this paper therefore must be hereby marked advertisement solely to indicate this fact.

${ }^{1}$ Servicio de Desarrollo Tecnológico Agrario.
}

Introduction of DNA-based markers has provided a large number of markers independent of environmental influences and are suitable for genetic typing at very early stages of development. Among the different markers, the simplicity of laboratory assays for randomly amplified polymorphic DNA (RAPD) markers (Williams et al., 1990), make them an attractive method for fingerprinting genotypes. This technique is already used for cultivar identification of commercial germplasm and protecting plant patents (Baird et al., 1996). In olive, RAPD markers have been used by Fabbri et al. (1995) and Wiesman et al. (1998).

The present study reports use of RAPD markers for identification of 40 closely related olive cultivars native to Valencia. Our objective was to provide markers that can identify all prominent cultivars, test their efficiency in discriminating closely related cultivars, and evaluate future RAPD marker applications for maintenance of olive germplasm.

\section{Material and Methods}

Plant materials studied are listed in Table 1 and included 40 accessions out of 217 identified in a survey of 32 counties belonging to three provinces of the Valencia region of Spain. Their distribution according to origin are illustrated in Fig. 1.

DNa ISOLATION. Fifty milligrams of young expanding leaves of each cultivar was collected on May, rinsed with tap water, placed in an eppendorf tube and kept at $-80^{\circ} \mathrm{C}$. Total DNA was isolated following the CTAB method of Doyle and Doyle (1987). Extracted DNA was diluted to $100 \mathrm{ng} \cdot \mathrm{mL}^{-1}$ for polymerase chain reaction (PCR) amplification. Three replicate DNA isolations from each cultivar were made.

RAPD ANALYSIS. Sixty-four decamer oligonucleotides (Kits OP-A, OP-B, OP-C, OP- J, OP-R, OP-V, OP-X, and OP-Y from Operon Technologies, Alameda, Calif.) were screened for polymorphism on DNA of 10 cultivars. From these, 32 were selected based on quality of the amplification products. These selected primers were used to screen all 40 cultivars. All reactions were performed in $25 \mathrm{~mL}$ volumes containing $10 \mathrm{~mm}$ Tris-HCl, $\mathrm{pH} 8.2$, $50 \mathrm{~mm} \mathrm{KCl}, 1.5 \mathrm{~mm} \mathrm{MgCl}_{2}, 200 \mathrm{~mm}$ primer, 0.5 unit of AmpliTaq DNA Polymerase (Life Technologies, Gaithersburg, Md.) and 25 ng DNA. Amplifications were performed in a thermal cycler, (Progene; Techne, Cambridge, United Kingdom) programmed for one cycle of 2 min at $94^{\circ} \mathrm{C}$, followed by 45 cycles of $1 \mathrm{~min}$ at $92{ }^{\circ} \mathrm{C}, 1 \mathrm{~min}$ at $33^{\circ} \mathrm{C}$ and $2 \mathrm{~min}$ at $72{ }^{\circ} \mathrm{C}$ (Badenes et al., 1998). 
Table 3. RAPD markers obtained from olive cultivars 1 to 20 . Numbers correspond to Table 1 . The way the bands are named: A1 = primer 1 from set $\mathrm{A}$, followed by the molecular weight in bp.

\begin{tabular}{|c|c|c|c|c|c|c|c|c|c|c|c|c|c|c|c|c|c|c|c|c|}
\hline \multirow[b]{2}{*}{ Markers } & \multicolumn{20}{|c|}{ Cultivar } \\
\hline & 1 & 2 & 3 & 4 & 5 & 6 & 7 & 8 & 9 & 10 & 11 & 12 & 13 & 14 & 15 & 16 & 17 & 18 & 19 & 20 \\
\hline A1-1100 & $1^{\mathrm{z}}$ & 1 & 1 & 1 & 1 & 1 & 0 & 1 & 1 & 1 & 1 & 0 & 1 & 1 & 0 & 0 & 1 & 0 & 1 & 0 \\
\hline A1-1200 & 1 & 0 & 1 & 1 & 1 & 0 & 0 & 0 & 0 & 0 & 0 & 0 & 0 & 1 & 1 & 0 & 0 & 0 & 1 & 1 \\
\hline A8-1175 & 1 & 0 & 1 & 1 & 1 & 0 & 0 & 1 & 0 & 0 & 1 & 0 & 1 & 1 & 1 & 1 & 1 & 0 & 0 & 1 \\
\hline A8- 1350 & 0 & 0 & 1 & 1 & 0 & 1 & 1 & 0 & 0 & 0 & 1 & 0 & 1 & 1 & 0 & 0 & 0 & 1 & 0 & 0 \\
\hline A8-900 & 0 & 1 & 1 & 1 & 1 & 0 & 0 & 1 & 1 & 1 & 1 & 0 & 0 & 1 & 1 & 1 & 0 & 1 & 1 & 1 \\
\hline B2-1600 & 0 & 0 & 0 & 1 & 1 & 0 & 0 & 0 & 0 & 0 & 0 & 0 & 0 & 0 & 0 & 0 & 0 & 0 & 0 & 0 \\
\hline B2-800 & 0 & 0 & 0 & 0 & 0 & 0 & 0 & 0 & 0 & 0 & 0 & 0 & 0 & 0 & 0 & 0 & 0 & 0 & 0 & 1 \\
\hline B6-1000 & 0 & 0 & 0 & 0 & 1 & 0 & 0 & 0 & 0 & 0 & 0 & 0 & 1 & 0 & 0 & 0 & 0 & 0 & $--^{y}$ & 0 \\
\hline B6-1200 & 0 & 0 & 1 & 0 & 0 & 1 & 0 & 0 & 0 & 0 & 0 & 0 & 1 & 1 & 1 & 0 & 0 & 0 & --- & 0 \\
\hline B6-600 & 1 & 0 & 1 & 0 & 0 & 0 & 0 & 1 & 0 & 1 & 1 & 1 & 1 & --- & 1 & 0 & 0 & 0 & --- & 1 \\
\hline B8->2000 & 0 & 0 & 0 & 0 & 0 & 0 & 1 & 1 & 0 & 1 & 0 & 1 & 0 & 0 & 0 & 1 & 1 & 0 & 0 & 0 \\
\hline B8-1250 & 0 & 1 & 1 & 0 & 1 & 0 & 1 & 1 & 1 & 1 & 1 & 1 & 0 & 1 & 1 & 0 & 0 & 1 & 1 & 1 \\
\hline C3->2500 & 1 & 1 & 1 & 0 & - & 0 & 1 & 1 & 1 & 1 & --- & 1 & --- & 0 & 0 & 1 & 1 & 1 & 1 & 0 \\
\hline C3-1500 & 0 & 1 & 1 & 1 & 0 & 0 & 1 & 1 & 1 & --- & 1 & 1 & 0 & 0 & 0 & 0 & 1 & 0 & 1 & 1 \\
\hline C4-1250 & 0 & 1 & 0 & 1 & 1 & 0 & 0 & 0 & 0 & 1 & 0 & --- & 1 & 1 & 1 & 0 & 0 & 1 & 1 & 1 \\
\hline C4-1500 & 1 & 1 & 1 & 1 & 1 & 1 & 0 & 1 & 0 & 0 & 0 & 1 & 1 & 1 & 1 & 1 & 1 & 1 & 1 & 1 \\
\hline C6-1100 & 0 & 1 & 1 & 1 & 1 & 1 & 1 & 0 & 1 & 1 & 1 & 1 & 1 & 1 & 1 & 1 & 0 & 1 & 1 & 1 \\
\hline C7-700 & 1 & 1 & 1 & 0 & 0 & 1 & 1 & 1 & 0 & 0 & 1 & 1 & 1 & 0 & 0 & 1 & 0 & 0 & 0 & 0 \\
\hline J5-1300 & 1 & 1 & 1 & 0 & 0 & 1 & 1 & 0 & 1 & 0 & 1 & 1 & 1 & 1 & 1 & 1 & 0 & 1 & 1 & 1 \\
\hline R2-1100 & 1 & 0 & 0 & 0 & 1 & 0 & 1 & 1 & 0 & 0 & 0 & 1 & 0 & 0 & 0 & 0 & 1 & 1 & 1 & 1 \\
\hline R3->1500 & 0 & 0 & 1 & 0 & 0 & 0 & 0 & 1 & 0 & 1 & 1 & 0 & 0 & 1 & 0 & --- & 1 & 1 & 0 & 1 \\
\hline R3-1000 & 1 & 0 & 1 & 1 & 1 & 1 & 0 & 0 & 0 & 1 & 1 & 1 & 1 & 1 & 1 & --- & 1 & 0 & --- & 0 \\
\hline R3-550 & 0 & 0 & 1 & 1 & 0 & 1 & 0 & 0 & 0 & 0 & 0 & 0 & 1 & 1 & 1 & --- & 0 & 0 & 0 & 1 \\
\hline R5-800 & 1 & 1 & 1 & 1 & 0 & 1 & 0 & 1 & 1 & --- & 1 & 1 & 1 & 1 & 1 & 1 & 1 & 1 & 1 & 1 \\
\hline V1-1000 & 0 & 0 & 0 & 0 & 0 & --- & 1 & 0 & 0 & 0 & --- & 0 & 0 & 1 & 0 & 0 & 0 & 0 & 0 & 1 \\
\hline V1-700 & 1 & 1 & 1 & 0 & 0 & --- & --- & 0 & 1 & 1 & --- & 1 & 0 & 0 & 1 & 1 & 1 & 1 & 1 & 1 \\
\hline X4-1000 & 1 & 0 & 0 & 0 & 0 & 0 & 0 & 0 & 0 & 0 & 0 & 0 & 0 & 1 & 1 & 0 & 0 & 1 & 1 & 1 \\
\hline $\mathrm{X} 4-625$ & 1 & 1 & 0 & 0 & 0 & 1 & 1 & 1 & 1 & 0 & 0 & 0 & 0 & 0 & 0 & 1 & 1 & 1 & 1 & 0 \\
\hline X4-700 & 0 & 1 & 1 & 1 & 1 & 0 & 1 & 0 & 1 & 0 & 1 & 1 & 1 & 1 & 1 & 0 & 1 & 0 & 1 & 1 \\
\hline $\mathrm{X} 5-1150$ & 0 & 1 & 1 & 0 & 1 & 1 & 1 & 0 & 1 & 1 & 1 & 1 & 1 & 0 & 0 & 1 & 1 & 1 & 0 & 0 \\
\hline X5-1400 & 1 & 1 & 1 & 0 & 0 & 1 & 1 & 1 & 0 & 1 & 0 & 1 & 1 & 1 & 0 & 0 & 1 & 1 & 1 & 1 \\
\hline X5-625 & 1 & 1 & 1 & 1 & 1 & 1 & 1 & 1 & 1 & 0 & 1 & 0 & 1 & 1 & 1 & 1 & 1 & 1 & 1 & 1 \\
\hline Y2-1100 & 1 & 1 & 0 & 0 & 0 & 0 & 1 & 1 & 1 & 0 & 0 & 0 & 1 & 1 & 0 & 0 & 1 & 1 & 1 & 1 \\
\hline Y3-1300 & 1 & 0 & 1 & 1 & 0 & 1 & 0 & 0 & 0 & 0 & 0 & 1 & 1 & 0 & 1 & 1 & 1 & 0 & 1 & 1 \\
\hline A1-1100 & 0 & --- & 1 & 0 & 1 & 1 & 1 & 0 & 1 & 0 & 1 & 0 & 1 & 0 & 0 & 1 & 1 & 1 & 1 & 1 \\
\hline A1-1200 & 1 & --- & 0 & 1 & 1 & 1 & 0 & 1 & 1 & 1 & 1 & 0 & 0 & 0 & 1 & 1 & 1 & 1 & 0 & 1 \\
\hline A8-1175 & 0 & 1 & 1 & 1 & 1 & 0 & 1 & 1 & 1 & 1 & 0 & 1 & 1 & 1 & 1 & --- & 1 & 1 & 1 & 1 \\
\hline A8-1350 & 0 & 0 & 0 & 1 & 1 & 0 & 0 & 1 & 0 & 1 & 0 & 0 & 1 & 1 & 0 & --- & 0 & 1 & 0 & 0 \\
\hline A8-900 & 1 & 0 & 1 & 1 & 0 & 1 & 1 & 1 & 1 & 1 & 1 & 1 & 1 & 1 & 1 & --- & 1 & 1 & 0 & 1 \\
\hline B2-1600 & 0 & 0 & 0 & 0 & 0 & 0 & 0 & 0 & 0 & 0 & 0 & 0 & 0 & 0 & 0 & 0 & 1 & 0 & 0 & 0 \\
\hline B2-800 & 0 & 0 & 0 & 0 & 0 & 0 & 0 & 0 & 0 & 0 & 0 & 0 & 0 & 0 & 0 & 0 & 0 & 0 & 0 & 0 \\
\hline B6-1000 & 0 & 1 & 1 & 0 & 0 & 0 & 0 & 0 & 1 & 0 & 0 & 0 & 0 & 1 & 1 & 1 & 1 & 1 & 1 & 0 \\
\hline B6-1200 & 0 & 0 & 1 & 1 & 1 & 0 & 0 & 0 & 1 & 0 & 0 & 1 & 0 & 0 & 0 & 0 & 1 & 0 & 0 & 0 \\
\hline B6-600 & 0 & 1 & 0 & 1 & 1 & 0 & 0 & 0 & 0 & 0 & 0 & 1 & 1 & 0 & 1 & 0 & 1 & 0 & 1 & 0 \\
\hline B8->2000 & 0 & 1 & 0 & 0 & 1 & 0 & 0 & 1 & 1 & 1 & 0 & 0 & 0 & 0 & 0 & 0 & 0 & 0 & 0 & 0 \\
\hline B8-1250 & 1 & 1 & 1 & 1 & 0 & 1 & 0 & 1 & 0 & 1 & 1 & 1 & 1 & 1 & 1 & 1 & 0 & 1 & 1 & 1 \\
\hline C3->2500 & 1 & 1 & 1 & 1 & 1 & 1 & 1 & 1 & 1 & 1 & 1 & 1 & 1 & 1 & 1 & 1 & 1 & 1 & 1 & 1 \\
\hline C3-1500 & 1 & 0 & 1 & 0 & 1 & 1 & --- & 1 & 1 & 1 & 1 & 1 & 0 & 1 & 0 & 0 & 1 & 1 & 0 & 1 \\
\hline C4-1250 & 0 & 1 & 1 & 1 & 1 & 1 & 1 & 0 & 1 & 1 & 1 & 0 & 1 & 0 & 1 & 0 & 0 & 0 & 1 & 1 \\
\hline C4-1500 & 1 & 1 & 1 & 1 & 0 & 1 & 0 & 1 & 1 & 1 & 1 & 1 & 1 & 1 & 1 & 1 & 1 & 1 & 1 & 1 \\
\hline C6-1100 & 1 & 0 & 1 & 1 & 0 & 1 & 1 & 1 & 1 & 1 & 1 & 1 & 1 & 1 & 1 & 1 & 1 & 1 & 1 & 1 \\
\hline C7-700 & 0 & 1 & 1 & 0 & 1 & 0 & 0 & 0 & 0 & 0 & 0 & 1 & 1 & 1 & 0 & 0 & 1 & 0 & 1 & 1 \\
\hline J5-1300 & 0 & 1 & 0 & 0 & 0 & 1 & 0 & 1 & 0 & 1 & 1 & 1 & 0 & 1 & 1 & 1 & 0 & 1 & 0 & 1 \\
\hline R2-1100 & 1 & 0 & 0 & 0 & 1 & 0 & 0 & 0 & 0 & 1 & 0 & 1 & 0 & 1 & 0 & 0 & 0 & 0 & 0 & 1 \\
\hline R3->1500 & 1 & 1 & 0 & 0 & 1 & 0 & 0 & 0 & 1 & 0 & 0 & 1 & 1 & 0 & 0 & 0 & 0 & 0 & 1 & 0 \\
\hline R3-1000 & 0 & 1 & 1 & 1 & 0 & 1 & 1 & 1 & 1 & 0 & 0 & 1 & 1 & 0 & 0 & 0 & 1 & 1 & 0 & 1 \\
\hline R3-550 & 0 & 1 & 1 & 1 & 1 & 0 & 0 & 0 & 0 & 0 & 0 & 1 & 0 & 1 & 1 & 1 & 1 & 0 & 1 & 0 \\
\hline
\end{tabular}


Table 3. Continued.

\begin{tabular}{|c|c|c|c|c|c|c|c|c|c|c|c|c|c|c|c|c|c|c|c|c|}
\hline \multirow[b]{2}{*}{ Markers } & \multicolumn{20}{|c|}{ Cultivar } \\
\hline & 1 & 2 & 3 & 4 & 5 & 6 & 7 & 8 & 9 & 10 & 11 & 12 & 13 & 14 & 15 & 16 & 17 & 18 & 19 & 20 \\
\hline R5-800 & 1 & 1 & 1 & 1 & 1 & 1 & 1 & 1 & 1 & 1 & 1 & 1 & 1 & 1 & 1 & 1 & 1 & 1 & 1 & 1 \\
\hline V1-1000 & 1 & 1 & 1 & 0 & 0 & 0 & 0 & 0 & 0 & 0 & 0 & 0 & 0 & 1 & 0 & 1 & 1 & 1 & 0 & 0 \\
\hline V1-700 & 0 & 0 & 0 & 0 & 1 & 1 & 1 & 1 & 0 & 1 & 1 & 1 & 0 & 1 & 0 & 1 & 0 & 1 & 1 & 1 \\
\hline X4-1000 & 1 & 1 & 0 & 1 & 0 & 0 & 0 & 1 & 1 & 1 & 1 & 1 & 0 & $*$ & 1 & 0 & 0 & 1 & 1 & 0 \\
\hline$X 4-625$ & 1 & 0 & 0 & 0 & 1 & 1 & 0 & 1 & 0 & 1 & 1 & 1 & 1 & 1 & 0 & 1 & 0 & 0 & 1 & 1 \\
\hline X4-700 & 1 & 0 & 1 & 1 & 1 & 1 & 1 & 1 & 1 & 1 & 1 & 0 & 1 & 0 & 0 & 0 & 1 & 1 & 0 & 1 \\
\hline X5-1150 & 1 & 1 & 0 & 0 & 0 & 1 & 0 & 1 & 1 & 0 & 0 & 0 & 1 & 1 & 1 & 1 & 1 & 1 & 1 & 1 \\
\hline $\mathrm{X} 5-1400$ & 1 & 1 & 0 & 0 & 1 & 1 & 1 & 1 & 0 & 1 & 1 & 0 & 1 & 1 & 1 & 1 & 1 & 1 & 1 & 1 \\
\hline X5-625 & 1 & 1 & 1 & 1 & 1 & 1 & 0 & 1 & 1 & 1 & 1 & 1 & 1 & 1 & 1 & 1 & 1 & 0 & 1 & 0 \\
\hline Y2-1100 & 1 & 1 & 1 & 0 & 0 & 1 & 1 & 1 & 0 & 1 & 1 & 0 & 0 & 1 & 0 & 1 & 1 & 0 & 0 & 1 \\
\hline Y3-1300 & 0 & 0 & 0 & 0 & 0 & 1 & 0 & 1 & 1 & 1 & 1 & 0 & 0 & 0 & 1 & 1 & 0 & 1 & 1 & 0 \\
\hline
\end{tabular}

${ }^{\mathrm{z}} 1=$ presence of band $0=$ absence of band.

${ }^{y}$ Data not taken into account due to no reproducibility.

Amplified products were size fractionated by electrophoresis in $2 \%$ agarose gels ( $1 \times$ TAE buffer), stained by ethidium bromide and photographed. Molecular sizes of the amplified fragments were estimated using a 100 base pair ladder (New England Biolabs, Beverly, Mass.). The ability of the amplification products to be reproduced was tested by using each primer on each of the three independent DNA isolations per cultivar. A bulked sample made from 10 cultivars was used as a positive control of amplifications. Only bands clearly polymorphic and reproducible were selected as markers.

Cluster analysis of RAPD markers from the 40 cultivars was performed using NTSYS (Exeter Software, Setauket, N.Y.), (Rolfh, 1993). Estimates of similarity according to the presence or absence of amplified bands were based on the number of shared amplification products. As genetic distance estimators, Nei's (Nei and Li, 1979) and Jaccard's (Sneath and Sokal, 1963) coefficients were used. Similarity matrices based on Nei's and Jaccard's analysis were compared using the Mantel matrixcorrespondence test (Mantel, 1967). A dendrogram was constructed based on Nei's similarity data applying the unweighted pair group method (UPGMA).

\section{Results}

PolymorPhism AND IDENTITY. Amplification was successful with all 64 primers, but only 32 primers generated polymorphic bands in the 10-sample screening set. These 32 primers were then used to screen 40 cultivars from the Valencia germplasm collection. Eighteen primers out of 32 were selected according to their reproducible amplification products. These 18 primers yielded 34 markers with an average of 1.9 markers / primer. The number of polymorphic fragments per primer ranged from one to three and fragment size ranged from $550 \mathrm{bp}$ (OPR-3) to $1350 \mathrm{bp}$ (OPA-8). The amplification products obtained by primer OPJ-5 are illustrated in Fig. 2, which exemplifies typical RAPD banding patterns observed. Table 2 shows the primers selected, the primer sequence, and the number of markers obtained in the 40-sample set and Table 3 lists markers obtained along with the presence or absence in the cultivars studied. All cultivars were identified by a unique combination of RAPD markers, using only 18 polymorphic primers.

Grouping OF CUltivars. Nei's and Jaccard's genetic distance estimator indices were compared in the analysis of olive RAPD diversity. Correlation between similarity matrices obtained with the two genetic distance estimators was $r=0.97(P<0.05)$. Since both estimators gave equivalent results, only the similarity matrix index using Nei's distance was used for subsequent cluster analyses.

Fig. 1.Location of the accessions included in the study. Numbers correspond to cultivars listed in Table 1. 


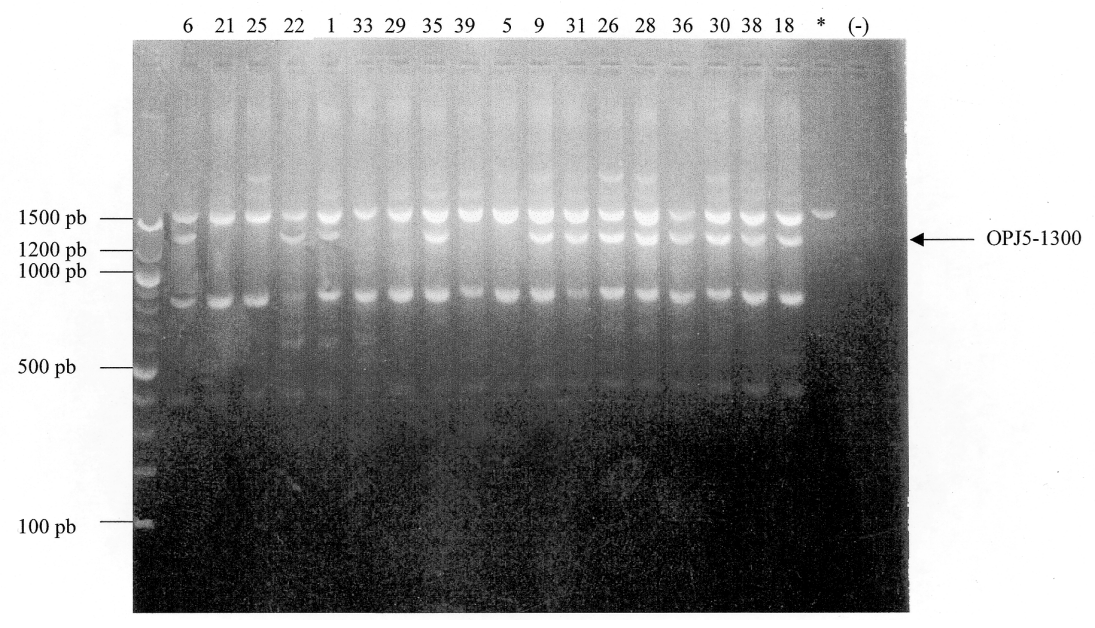

Fig. 2. Amplification products from primer OPJ 5. From left to right:100 bp ladder , 'Borriolenca', 'Manzanilla Cacereña', 'Penjoll', 'Manzanilla de Caudiel', 'Aguilar', 'Rufina', 'Plans', 'Solà', 'Vilar', 'Blanqueta Gorda', 'Carrasqueña de Cañada', 'Rojal de Cañada', 'Pico de Limón', 'Piñon', 'Tardía Puebla',

'Racimo', 'Vera', 'Gorda-Limoncillo', (*) positive control, (-) negative control.

Two main clusters of Valencian cultivars were observed in the dendrogram (Fig. 3) resulting from cluster analysis. The first cluster included 22 cultivars, mostly from Valencia and Alicante, with only three exceptions that were selected in Castellón and clustered in the Valencia-Alicante group ('Serrana Espadán', 'Tardía Puebla', and 'Llumeta'). A second cluster included cultivars from Castellón with four exceptions that corresponded to cultivars selected at Valencia ('Blanqueta', 'Blanqueta Gorda', 'Cuquillo', and 'Dulce'). Two cultivars, 'Cornicabra' and 'Picual', from outside of Valencia, were included in the study to test the cluster analysis. They were clustered apart from Valencian cultivars. No grouping of cultivars correlating to morphological characteristics were observed, with the exception of 'Cuquillo' and 'Arbequina' that clustered together and represented the two cultivars within the collection with the smallest fruit.

\section{Discussion}

Polymorphism and IDENTITy. The frequency of polymorphism obtained was 34 markers $/ 18$ primers selected. This is higher than the rate obtained in olive by Fabbri et al. (1995) of 47/40 and much lower than that reported by Wiesman et al. (1998) of 80/20. Olives are considered a highly heterozygous species. In terms of identified polymorphism, our results did not contradict this. Although the cultivars studied were closely related, we found 18 primers yielding 34 markers that could discriminate all cultivars. A high discriminating ability of RAPD markers applied to olive tree was also found by Wiesman et al. (1998). However, there are differences between the rate of polymorphism yielded by primers in the Wiesman study (4 markers/primer) and our study (1.9 markers/primer), which could be explained by differences in the primer sets used, between the population analyzed, and in the criteria for selecting markers. For example, in this study, faint bands or those that were not reproducible after three independent amplifications from three independent DNA isolations were not taken into account, which may not have been the criteria used by Wiesman et al. (1998).

Grouping of Cultivars. The data obtained in the present

Table 1. Cultivars included in this study and their province of origin within Valencia.

\begin{tabular}{|c|c|c|c|}
\hline Cultivar & Province of origin & Cultivar & Province of origin \\
\hline 1. Aguilar & Valencia & 21. Manz.Cacereña ${ }^{z}$ & Valencia $^{\mathrm{y}}$ \\
\hline 2. Alfafara & Valencia & 22. Manz.Caudiel ${ }^{\mathrm{x}}$ & Castellón \\
\hline 3. Arbequina & Castellón ${ }^{\mathrm{y}}$ & 23. Morrut & Castellón \\
\hline 4. Blanqueta & Alicante & 24. Nana & Castellón \\
\hline 5. Blanqueta Gorda & Alicante & 25. Penjoll & Castellón \\
\hline 6. Borriolenca & Castellón & 26. Pico de Limón & Alicante \\
\hline 7. Cabaret & Valencia & 27. Picual & Valencia $^{\mathrm{y}}$ \\
\hline 8. Callosina & Alicante & 28. Piñón & Valencia \\
\hline 9. Carrasqueña ${ }^{\mathrm{w}}$ & Alicante & 29. Plans & Valencia \\
\hline 10. Cornicabra & Valencia $^{y}$ & 30. Racimo & Valencia \\
\hline 11. Cuquillov & Valencia & 31. Rojal de Cañada & Alicante \\
\hline 12. Changlot Real & Alicante & 32. Rojal de Valencia & Valencia \\
\hline 13. Dulce & Valencia & 33. Rufina & Valencia \\
\hline 14. Empeltre & Castellón & 34. Serrana de Espadán & Castellón \\
\hline 15. Farga & Castellón & 35. Solà & Castellón \\
\hline 16. Genovesa & Valencia & 36. Tardia Puebla ${ }^{\mathrm{u}}$ & Castellón \\
\hline 17. Gordal Sevillana & Valencia $^{y}$ & 37. Temprana Montán & Castellón \\
\hline 18. Gorda-Limoncillo & Valencia & 38. Vera & Valencia \\
\hline 19. Grosal de Solana & Valencia & 39. Vilar & Valencia \\
\hline 20. Llumeta & Castellón & 40. Villalonga & Valencia \\
\hline
\end{tabular}

\footnotetext{
z‘Manzanilla Cacereña'.

ySeedling from a cultivar from Catalonia, selected at Valencia or Castellón.

x'Manzanilla de Caudiel'.

w'Carrasqueña de Cañada'.

'CCuquillo-Lechín de Granada'.

u'Tardía de Puebla de Arenoso'.
} 
Table 2. Selected primers, sequence, and number of markers produced among the 40 cultivars studied. See Table 3 for size of the polymorphic fragments obtained.

\begin{tabular}{lcccc}
\hline \hline Primer & Sequence $5^{\prime} \longrightarrow 3^{\prime}$ & Fragments (no.) & Primer & Sequence 5 $^{\prime} \rightarrow 3^{\prime}$ \\
\hline OPA1 & CAGGCCCTTC & 2 & OPJ5 & CTCCATGGGG \\
OPA8 & GTGACGTAGG & 3 & OPR2 & CACAGTTGCC \\
OPB2 & TGATCCCTGG & 2 & OPR3 & ACACAGAGGG \\
OPB6 & TGCTCTGCCC & 3 & OPR5 & GACCTAGTGG \\
OPB8 & GTCCACACGG & 2 & OPV1 & TGACGCATGG \\
OPC3 & GGGGGTCTTT & 2 & OPX4 & CCGCTACCGA \\
OPC4 & CCGCATCTAC & 2 & OPX5 & CCTTTCCCTC \\
OPC6 & GAACGGACTC & 1 & OPY2 & CATCGCCGCA \\
OPC7 & GTCCCGACGA & 1 & OPY3 & ACAGCCTGCT \\
\hline
\end{tabular}

study shows a correlation between the grouping of olive cultivars and their geographic origin within Valencia, according to provinces, but not by county of origin. In retrospect this seems logical : counties are not geographically isolated, because of the movement and exchange of germplasm among counties is very improbable that unique cultivars evolved in an specific county. Two main clusters were observed, the first included mostly cultivars from Valencia and Alicante (Fig. 1), with only three exceptions out of 22. A second main cluster included cultivars from Castellón with five exceptions. Two cultivars originating outside Valencia, 'Cornicabra' and 'Picual', were included in the study as reference cultivars. These reference cultivars were clustered apart from Valencian cultivars, in agreement with previous results based on isozymes obtained by Trujillo et al. (1990) who also observed that groups of cultivars were clustered according to their origin within Spain. Our findings agree with those of Trujillo et al. (1990) which are similar to results here in, they also studied cultivars predominantly from a single region in Spain. In contrast to our study, Fabbri et al., (1995), obtained a clustering of cultivars according to fruit size with no correlations between DNA polymorphism and site of cultivar origin. A possible explanation for differences between the results of Fabbri et al. (1995) and ours and those of Trujillo et al. (1990) could be that Fabbri et al (1995) studied 17 cultivars from 10 different countries, with some countries represented by only one or two cultivars. The sampling (number of cultivars studied and origins) of Fabbri et al. (1995) may have not been large enough to detect associations within a single country. Fabbri et al. (1995) said a possible explanation for their results was that early in its domestication, olive cultivars of horticultural value were moved from one region to region.

Results here indicate that the germ-
Fig. 3. Dendrogram obtained by UPGMA cluster analysis from the similarity matrix obtained by Nei's genetic distance.

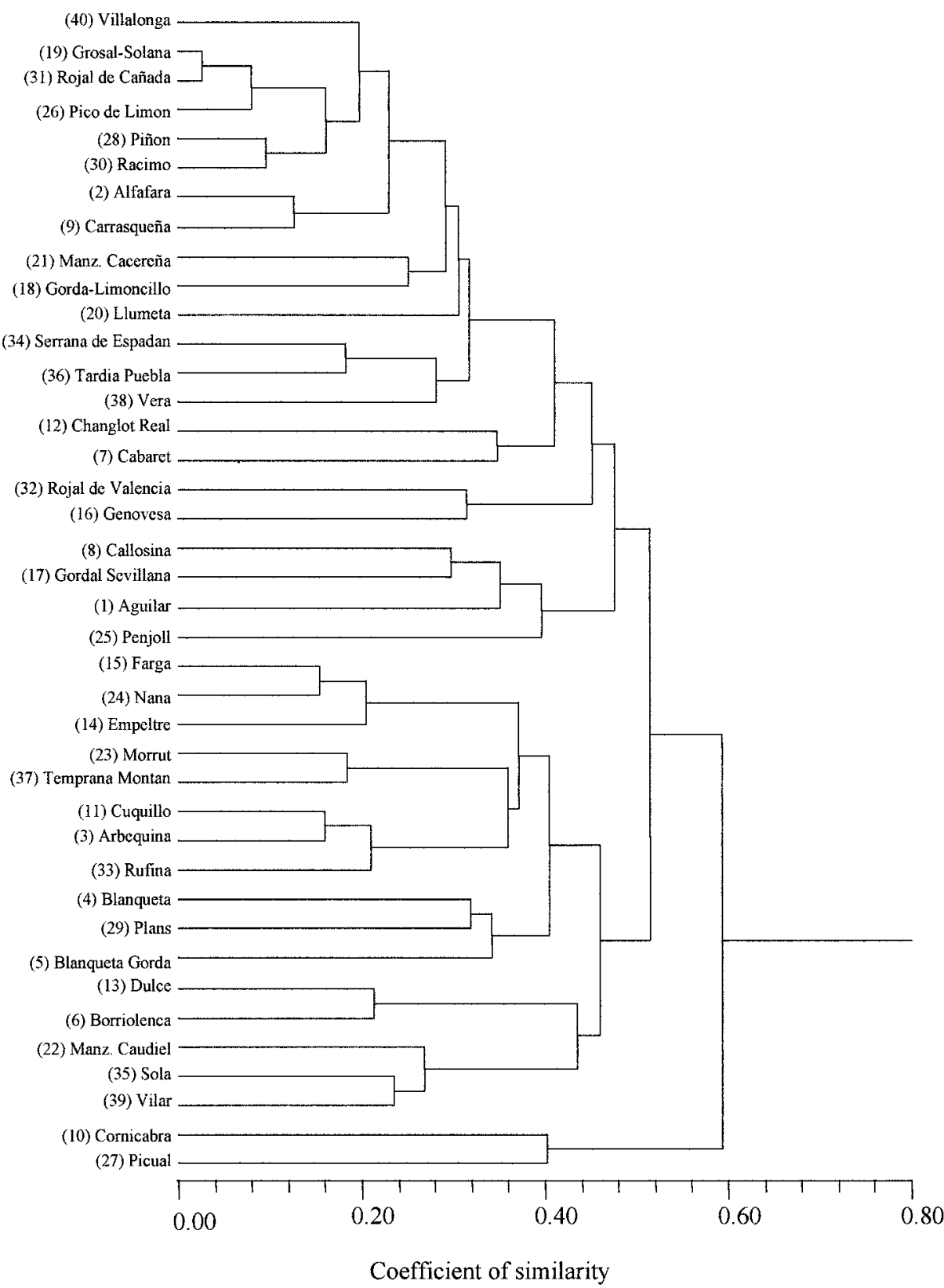


plasm studied appears to belong to two populations obtained by clonal propagation of seedlings followed by local selection. A cluster that grouped cultivars from Valencia and Alicante makes sense since counties belonging to these two provinces are close geographically (Fig. 1). This is expected as dispersion within these regions has no geographic barriers. Similar results were obtained in apricot (Prunus armeniaca L) using amplified fragment length polymorphism (AFLP) markers (Hurtado et al., 1999). These highly effective markers were able to group apricot cultivars according to their specific local origin. RAPD technology applied to olive is as effective as AFLP markers in apricot for fingerprinting cultivars. We conclude that RAPD technology is a good tool for fingerprinting closely related olive cultivars. However, we strongly suggest stringent selection of markers. Due to the dependence from the technical conditions of RAPD technology, selection of polymorphic markers should be based on highly reproducible bands.

\section{Literature Cited}

Badenes, M.L., J. Martínez-Calvo, and G. Llácer. 1998. Analysis of peach germplasm from Spain. Acta Hort. 465: 243-250.

Baird, W.V., R.E. Ballard, S. Rajapakse, and A.G. Abbott. 1996. Progress in Prunus mapping and application of molecular markers to germplasm improvement. HortScience 31:1099-1106.

Barranco, D. 1998. Variedades y patrones, p. 61-87. In: D. Barranco, R. Fernández-Escobar, and L. Rallo (eds.). El cultivo del olivo. 2nd ed. Mundiprensa y Junta de Andalucia, Madrid.

Barranco, D. and L. Rallo. 1985. Las variedades de olivo cultivadas en Andalucia. Consejeria de Agricultura de la Junta de Andalucia. Ministerio de Agricultura Pesca y Alimentación, Madrid. p. 27-63.

Doyle, J.J. and J.L. Doyle. 1987. A rapid isolation procedure for small quantities of fresh leaf tissue. Phytochem. Bul. 19:11-15.

Fabbri, A., J.I. Hormaza, and V.S. Polito. 1995. Random amplified polymorphic DNA analysis of olive cultivars. J. Amer. Soc. Hort. Sci. 120:538-542.

Hurtado, M.A., M.L. Badenes, G. Llácer, E. Beck, A. Westman, and A.G. Abbott. 1999. Caracterización de variedades de albaricoquero por medio de marcadores moleculares tipo AFLP ( amplified fragment length polymorphism). Actas de Horticultura 25:192-196.

Iñiguez, A., S. Paz, and L. Sánchez. 1999. Variedades del olivo de la C. Valenciana. Cuadernos de Tecnología Agraria. Serie Olivi-cultura. Generalitat Valenciana. Conselleria de Agricultura, Pesca y Alimentación 1:5-23.

Mantel, N.A. 1963. The detection of disease clustering and a generalized regression approach. Cancer Res. 27:209-220.

Nei, M. and W.H. Li. 1979. Mathematical model for studying genetic variation in terms of restriction endonucleases. Proc. Natl. Acad. Soc. USA 76:5269-5273.

Rohlf, F.J. 1993. NTSYS-PC numerical taxonomy and multivariate analysis system. Version 1.8. Exeter Publications, Setauket, N.Y.

Sneath, P.H.A. and R.R. Sokal. 1963. The principles and practice of numerical classification. WH Freeman, San Francisco.

Trujillo, I, L. Rallo, E.A. Carbonell, and M.J. Asins. 1990. Isoenzymatic variability of olive cultivars according to their origin. Acta Hort. 286:137-140.

Wiesman, Z., N. Avidan, S. Lavee, and B. Quebedeaux. 1998. Molecular characterization of common olive cultivars in Israel and the West Bank using randomly amplified polymorphic DNA (RAPD) markers. J. Amer. Soc. Hort. Sci. 123:837-841.

Williams, J.G.K., A.R. Kubelik, K.J. Livak, J.A. Rafalski, and S.V. Tingey. 1990. DNA polymorphism amplified by arbitrary primers are useful as genetic markers. Nucleic Acids Res. 18:6531-6535.

Zohary, M. and P. Spiegel-Roy. 1975. Beginnings of fruit growing in the Old World. Science 187:319-327. 